\title{
The Practice of Profit and Loss Sharing System For Rice Farmers in East Java, Indonesia
}

\author{
Umrotul Khasanah', Ubud Salim², Iwan Triyuwono ${ }^{3}$, Gugus Irianto ${ }^{4}$ \\ ${ }^{I}$ The lecturer of Faculty of Economic, State Islamic University Maulana Malik Ibrahim, Malang, East Java, \\ Indonesia. \\ ${ }^{234}$ The lecturer of Faculty of Economic and Business Brawijaya University, Malang, East Java, Indonesia.
}

\begin{abstract}
This research is aimed to explore: (1) the practice of profit and loss sharing (PLS) among the rice farmers society, (2) the meaning of PLS for rice farmers society. This qualitative research employs Giddens' structuration approach. The data analysis is executed through data collection, reduction and presentation which lead to the findings, proposition and conclusion. The research findings show that: (1) The PLS practice covers: (a) partnership as a work basis, (b) the priority of equity capital, (c) the one-third share model (2:1) and onehalf share model (1/2:1/2) of PLS (2) PLS has: (a) equality; (b) prosperity; (c) mutual cooperation; (d) ta'awun meanings.
\end{abstract}

Keywords: Profit and Loss Sharing (PLS), Partnership, one-third share, and one-half share model.

\section{Introduction}

The profit and loss sharing (PLS) practice in the agricultural production of rice is interesting and unique if it is related with the high cost of production and rent or the land price of the agriculture in East Java, Indonesia. The industrial vast development of non-agricultural business and the decrease of agricultural land as the cause of the shifted function into the non-agricultural sector seriously affect the increasing rice production's capital.

Although the agricultural cost of production and the cost of land increase, the rice farmers still survive and keep producing crops as the people's staple food. One of the factors that keep supporting the existence of rice farmers in producing rice is the financing model based on the profit and loss sharing system (PLS) developed by most rice farmers, namely one-third share/sepertigaan and one-half share/separuhan model. The models are local tradition of Islamic heritage passed on from the former generation practiced by the rice farmers for financing their rice cultivation.

The PLS phenomena, as relates to the agricultural profit and loss sharing in Java has been maintained for a long time. In accordance with Mustopo (2001), the occurrence of cultural transitional process in East Java is the synthetic result of Hindu-Buddhist culture with Islamic cultural elements during the XIV-XVI century. It happens in the era of Majapahit Kingdom and the establishment of Islamic Kingdom namely Mataram and Demak. Majapahit Kingdom was the biggest dynasty before Indonesian Archipelago is formed as Republic of Indonesia. Islam then entered Indonesia and affected the cultural tradition values within the palace and farmer society's environment since Majapahit was well known as agricultural and maritime nation.

The same opinion was proposed by Perwataatmadja (1996) that the adoption of Islamic values into the Islamic finance system occurs simultaneously with the Islamization process in Indonesia, mainly in Java. Islam encourages the process of applying Islamic values in various sectors of life such as economic, politic, social, and culture into agricultural sector. Referring to Hefner (2000), the Islamization process takes part in the local values which is then acculturated into the source of the society's productive work ethic. Because of the rich sense of equality within Islamic principles that influences the society's attitude in economics, those values become the driving force of equality enforcement among the community's economic life.

Based on the agricultural census (1993 and 2003), the category of small farmers who possess less than 0.50 hectare of land have reached $52.5 \%$. It proves that the ownership of the narrow and unstable agricultural land in the villages become worse since the unemployment number increases along with only a few vacant jobs available. It has encouraged people to use PLS as an instrument to create jobs opportunity and improve their incomes (Mubyarto, 2003; Kuncoro, 2002).

Nowadays, agriculture, the food production or the provision of rice in particular, has a strategic role since most of the people consume rice as their staple food. Thus, the position of rice farmers is very strategic because the provision of rice production really depends on their works. However, their dilemmatic position as farmers becomes a problem since they face three serious obstacles. The first one is the shrinkage of farmland for producing rice, in particular. Second, the increasing operational cost of rice production since the fertility level of land keeps decreasing. Hence, extra cost is needed to buy manure and also pesticides. The last obstacle is the limited financial capital provided to finance the agricultural production. 
Indonesian government has struggled to overcome the agricultural financing obstacle through conventional banking credits facility. However, the credit assistance program intended for farmers is considered ineffective, according to the research of Yasin (2008). The cause of the ineffectiveness of that farm credit is not only the technical banking, the farm credit financing via conventional banking, but a more complex obstacle also occurs. The interest-based farm credit is declared as a form of riba so Islam proscribes bank interests; meanwhile, most of farmers are Muslims.

According to Ashari and Saptana (2005), credit program with interest causes a new problem for farmers. It leads to the farmer's debt accumulation and bad debt credit. Therefore, it is important to find an effective instrument to deal with agricultural financing. It achieves a good response from sharia banks through their financing schemes: murabahah and Profit and Loss Sharing (PLS). Murabahah scheme is distributed by bai' salam instrument. PLS is distributed by mudharabah and musyaraah instruments.

The PLS model implemented by farmers is not suitable with the facilities given by Indonesian Islamic finance companies. As stated by Antonio (2001), PLS system commonly practiced by Islamic banking consists of at least four transactions: mudharabah, musyarakah, muzara'ah, and musaqoh. But only two transactions are commonly practiced in Indonesia. They are mudharabah and musyarakah. Muzara'ah and musaqoh have not implemented in sharia banking transaction system eventhough they are directly related to agricultural world. Muzara'ah particularly related to PLS agreement in rice cultivation. However, they are commonly implemented among farmers.

Based on prior theory and study, the researchers want to do a deeper study on PLS practice and explore its meaning among rice farmers in Kota Malang and Kabupaten Malang, East Java. The findings are expected to enrich Islamic bank financing study and develop Islamic bank financing facilities which are suitable with actual rice farmer financing practice.

\section{Islamic Finance System}

\section{Literature Review}

Rosly (2005) states that Islamic finance is a part of Islamic economic science, thus, Islamic economic science is the Islamic finance's subject. Choudhury and Hussain (2005) stated, the Islamic finance paradigm is based on the theology of the oneness of God (Tauhid) using the principle to refuse the system of interest in every kind of transaction. The Islamic finances instruments are divided into two instruments, bay' (sales and purchases) and profit and loss sharing (PLS) based instruments.

Bashir (2002) states that Islamic finance has proved that it can improve the prosperity whereas inflation has precisely decreased prosperity and inhibited economic growth. Thus, his party suggests to exchange the fixed interest rate system with variable of the PLS system based rate of return. Under the PLS management, the deposit within the finance institution receives its share of profit from bank whereas loan can be an equity.

The system differences of capitalist and Islamic finance, according to Chapra (2000), lie on its emphasis that is the Islamic finance which has a commitment in spiritual, socio-economic equality, and brotherhood of humanity values.

\section{Profit and Loss Sharing System}

Etymologically, Profit and Loss Sharing (PLS) means the sharing of profit and loss in a business. PLS is rooted and based on Islamic finance. According to Kamus Istilah Keuangan dan Perbankan Syariah BI (2006), profit sharing is the profit distribution between Islamic bank and its customers; the main principle executed by Islamic bank. The relationship existed in the profit sharing is the relationship between the capital owner (shahibul mal) and workers (mudharib). In the classical Islamic literature, referring to Nienhaus (1983), one of Islamic finance system characteristics is the comprehensive PLS model based on business transactional model.

In the term of agriculture, the meaning of PLS covers the definition of profit sharing and bear loss sharing. Hence, the business profit is shared based on the specific proportion as written in the initial agreement made by both parties, land or capital owners (capitalist) (shahibul maal) with sharecroppers (mudharib). The sharing of chance of loss, in which the result is uncertain, causes the shahibul maal to experience capital reduction or removal and the mudharib experiences the loss of chance and time in achieving the profit (Muhammad, 2005).

In Islamic fiqh, there are PLS models which are specifically used in agriculture, muzara'ah and musaqah. Muzara'ah is usually applied in agricultural cultivation pattern such as rice cultivation. The collaboration is formed through the cultivation of a plot of paddy field by land owners and sharecroppers in which the profit and loss sharing are applicable for the shahibul maal and mudharib. Musaqah, on the other hand, is more closely related to plantation, especially the plantation of fruit plants, such as dates, apples, or mangos. The plantation's owner (shahibul maal) cooperate with the farmers to maintain and preserve the trees to keep its productivity so that the PLS system can be applied in the harvesting time (Haroen, 2000; Qardhawi, 2002). 


\section{The Marginalization of Agricultural System}

Based on Tetanel (2008), Indonesia is estimated to experience food crisis in 2017. The indications can be seen since a long time ago such as the scarcity of soybean, and also the import of rice, sugar and other food commodities. Furthermore, the increase of beef price followed by the beef extinction becomes the first indication which states that the Indonesia's food sector is not stable. It is contrast with the fact that in the era of New Order Indonesia has achieved the United Nation's award for self-supporting in rice in 1984.

Sajogyo (2002) argues that the marginal problem in agricultural sector is actually an error in the structural development design. Because of it, the society must create a structural adjustment. The number of small farmers has increased during the 1990 decade. The land, which is less than 0.5 ha, is tried to be improved into $1.5 \%$ and the share croppers are increased into 5.0\% per year. The climax of those errors is resulted in 1998 when Indonesia import 6 million tons of rice and achieve the biggest number of rice import in history, 25\%.

\section{Method}

The study employs qualitative research method using Giddens' structurational approach. It emphasizes the mean, context, and emic perspective. Data analysis is done by collecting, presenting and reducing data to meet findings, propositions, and conclusions. Data collecting and analysis are done simultaneously; by prioritizing observation, interview, and also the writer, as its main instruments.

The design of the research emphasizes Gidden multiple hermeneutics, that is interpreting social practice with two interpretation levels. First interpretation is to understand PLS practice among rice farmer society according to their understanding, conception, belief, and interpretation. Second interpretation is the researcher's interpretation toward the first interpretation by uplifting it to a higher language (metalanguage). The interpretation process involves concept or construction employment using common scientific inventory (Giddens, 1984).

\section{The Practice of Rice Farmer's Profit and Loss Sharing (PLS) 1.1 Partnership as a Work Basis}

Rice farmers consider that rice has became staple food for most people. For them, consuming rice is considered as a welfare achievement. People who have rice as their staple are seen as more settled than those who consume other foods such as corn, cassava or sweet potatoes. Therefore, planting paddy is a rational choice to fulfill their basic needs. The availaibility of staple food, that is rice, becomes a daily main problem. Along with demographic population growth, there are social facts on land ownerships, particularly the farm land which used as a media for productive crops. The facts demand the society to possess and own land for the interest of crops area and even other interests such as residence and property industry which can be reflected through office, shop, resort and hotel, apartment, etc, for instance.

With an increasing tendency on land use for sectors other than agriculture, the number of landless farmers also increase. Nowadays it occurs within the farmers' society and leads to the splitting up of paddy farmer into two parts They are land owner and landless farmer consisting of sharecropper and farm labours.

According to the farmer'ssociety, the demography factor is not only dividing farmer society into two groups. It leads rice as a staple food and furthermore as society main occupation. In Kota Malang, it is about $10 \%$ of its households that has occupations as farmers. Whereas, in Kabupaten Malang, the number reaches $60 \%$.

The dividing process eventually demands a partnership pattern in order to make rice cultivation as an occupation. Logically, farmers who possess and own larger land can not do the land tenancy by themselves. Therefore, it is reasonably possible to make partnership pattern between the land owner and the sharecropper in rice cultivation.

Field data reveals that partnership as the groundwork for profit and loss sharing (PLS) system is a logical reality as a consequence of the increasing rice cultivation. The demand of demography growth and land ownership legalisation divide the rice farmers into two groups, land owner and landless farmer or farm labourer. The structure shows at least two elements in rice cultivation management. They are the existence of investors (shohibul maal) as principals and landless farmer (mudhorib) as agents or management employees. The existence of two parties in one management urges the need of strong foundation that is partnership system. It is a system based on an agreement among parties in rice cultivation management.

The discussion on the field findings fits a conception in Quran (Surah Yaasin: 33-35). It states that in natural food production system, there are three important things in food making process of a plant: land, water and seed. According to Quran, there are two ways for human to earn income or to fulfill their consumption needs: by directly consuming natural products such as fruit or grain like rice and working them out with their skills. In other words, food production, in order to fulfill their consumption, needs humans that rely on two factors. First, the factor of asset ownership can earn their income and second, the skill creativity or ability. 
The concept of partnership in managing rice production is in accordance with another verse in Quran (Surah Annisaa: 1). It states that partnership is important in life. The partnership principle in helping each other based on Quran must be positively constructed, to build good deeds and piety in human life. So the goal of partnership is not being liberal, unlimited freedom and merciless (Surah Al Maidah: 2). Not only to build good deeds and piety, partnership is also built on the sharing social solidarity, distributing income and opening job opportunities.

The previous study reveals that smaller farm land ownership and the inequality in country, according to agricultural census (1993 and 2003) the number of minor farmers attains 52.5\% whose land is less than 0.5 hectare, the high number of unemployment and the low number of job opportunities drive the society to implement PLS as an instrument to create job opportunities and increase their income (Mubyarto, 2003; Kuncoro, 2002). Based on the existing facts, it can be formulated that rice is a strategic comodity because it is a staple food and it also becomes farmer life income. To achieve optimal productivity, rice cultivation needs good management, that is by implementing partnership management based on PLS.

\subsection{Prioritizing Equity Capital}

According to farmers, they face at least three serious problems: the high price of land because of land area, quality, and soil fertility decrease. They trigger price uncertainty and unstability. Because of this capital problem, many farmers choose profit and loss sharing (PLS) practice in managing their rice cultivation.

The above three problems: the high price of land, highly cost maintenance, and unstability of input-output price, which accumulatively are the capital for planting rice, highly increase. In order to obtain capital for their rice production financing, farmers undertake some ways to get capital for their farm.

According to the farmers, at least they get the capital for financing their rice cultivation through four models. They are explained in the following table:

\section{Table 1:}

Farmers' Models in Obtaining Rice Cultivation Capital

\begin{tabular}{|c|l|}
\hline Model & \multicolumn{1}{c|}{ Ways In Obtaining Capital } \\
\hline 1 & Farmers who use capital from conventional or sharia financial institutions. \\
\hline 2 & $\begin{array}{l}\text { Farmers whose capital relies on government supporting programs. It can be in the form of } \\
\text { low interest-loans or grants like capital assistance, seed, fertilizer, and pesticide. }\end{array}$ \\
\hline 3 & Capital obtained by farmer by borrowing or being on credit to traders with ijonsystem \\
\hline 4 & Capital of rice farmers obtained by sharing system or Profit and Loss Sharing (PLS). \\
\hline
\end{tabular}

Based on existing theories, from those financing models, they can be classified into two models: debt financing and equity financing. Financing obtained from financing institutions, government, and ijon system can be classified as debt financing.

Theoretically, source of capital is obtained in two ways; by using private capital and other sources' capital. Capital from other sources or in finance terminology is called external capital, consists of two models: debt financing and equity financing. Allowed instruments in Islamic debt financing system consist of: murabahah, bay' bittaman ajil, bay' salam, bay' istisna' and ijarah. While Islamic equity financing system consists of mudharabah and musyarakah (read: Bank Islam Malaysia Berhad, 1994).

\subsection{PLS Model Form: One-Third and One-Half Share Model}

Based on observation and deep interview on rice farmers, there are two models of PLS-based rice production management: one-third and one-half share. Partnership in rice cultivation with these models involve two parties, land owner and sharecropper. Stock composition in rice cultivation with these two models is reflected from the task and obligation of each party. In the operational process of rice cultivation, sharecroppers directly employ hodge (farm labourer) as stakeholders.

Ownership factor or land tenure has a great role in rice cultivation management model in this one-third share model. Based on land tenure, both rice PLS models can be explained below:

(a). One-Third Share Model, land owner has the duty of providing lands, rice seeds, fertilizer and pesticides. On the other hand, the obligation of sharecroppers is working on land management from sowing seeds to harvesting crops. Sharecroppers employ hodges in their operational activities. The process implementation of profit and loss sharing is usually done after the harvest and overall yields are collected and weighed. After knowing the total of grain yields, it will be shared between land owner and sharecroppers according to the earlier agreement. The sharing ratio is $2: 1,2 / 3$ for land owner and 1/3 for sharecropper.

(b) One-Half Share Model, land owners only have the duty of providing land, while seed, fertilizer and pesticides, and workmanship land from sowing seeds to harvesting process are undertaken by sharecroppers. Sharecroppers employ hodges in their operational activities. The sharing implementation will be done after the harvest finishes. After knowing the overall grain yields, it will be cut for tithe but not for operational cost 
because it is the land owner's responsibility. After that, it will be shared with $1: 1$ ratio which means the total harvest result is divided into two parts equally between land owner and sharecropper.

In prior studies, Magnan (2005) states that companies which adopt PLS system in their strategic business unit show more superior in their asset growth than those which do not adopt it. Meanwhile, Hasan (1985) in his research states that PLS mudharabah model promotes growth policy as a tool to guarantee distributive equality.

In both models of PLS system applied in rice farmer society, it is also found that the whole process of profit sharing distribution is made after the harvest is completed. Based on the fact, the practice of PLS among rice farmer society is suitable with Islamic sharia. Prophet Muhammad once proscribed and allowed muzara'ah practice. The permission or proscription through muzara'ah practice is based on law of illat (legal reason).

Practice applied by those rice farmers is in accordance with Islamic sharia. A hadith by Handzalah Bin Qais from Rafi' bin Khadij states about the permission or proscription of muzara'ah system. Prophet prohibits if the sharing system is determined in the beginning because it contains speculation. If it does not harm one of two parts nor the absence of speculation and the sharing system is determined after harvesting, muzara'ah is permitted. (Shahih: Irwa-ul Ghalil V: 299, Fathul Bari V: 25 no: 2347 and 46, Nasa'i VII: 43 without any word of al-Laits).

\section{The Meaning of PLS for Rice Farmers \\ 2.1. The Meaning of Equality}

Based on the field study on rice farmer society, profit and loss sharing system (PLS) can be an effective instrument to transfer income distribution among parties involved in rice cultivation. PLS system becomes media which balance the income circulation, so there is no wealth accumulation in certain groups in society and no excessive social and economic inequality. Therefore, PLS has a meaningful purpose to create economic equality for its society.

PLS becomes the instrument of transferring wealth from the rich who has capital to various rice farmer societies, so there will be economic balance. In other words, PLS becomes the instrument to create economic justice in the system which includes rice farmer society.

It is accordance with Islamic teaching which states that mu'amalat system becomes the media to transfer the wealth so that it will not circulate among the rich people only. All things come from Allah must be distributed equally to all social levels especially for the weak like the poor, orphanage or $i b n u$ sabil, that is the people who fight in the path of Allah (Quran, Al-Hasyr: 7).

In the beginning process when muzara'ah was implemented by Prophet Muhammad, it is clearly seen that the motive of muzara'ah system emphasis is to create economic equality. Prophet Muhammad prohibits wealth accumulation and waste of asset.

Therefore, Prophet Muhammad emphasizes the productivity of our asset and prohibits us to accumulate wealth without caring about the poverty in our surrounding (Engineer, 2000).

\subsection{The Meaning of Prosperity}

The finding in the field shows the application of PLS system in the farm management of rice cultivation. PLS models do not only give big advantages toward the people which are directly involved, but they also give influence to the welfare of the society.

According to Bashir (2002), PLS is proved to be able to improve the welfare, while inflation, on the other hand, decrease the welfare and retard the economics growth. Furthermore, this model also shows that the government in the Islamic economy can effectively coordinate with the fiscal and monetary policy to support fund through tithe and ownership rights.

\subsection{The Meaning of Partnership}

The main characteristic of Profit and Loss Sharing (PLS) system in the management of rice cultivation is the partnership which is based on the high companionship value and strong affection among every party included in the rice cultivation. The partnership in rice cultivation is the reflection of the traditional value, that is passed on from the former generation that becomes a part of the rice farmers' daily life.

In fact, the rice farmers apply the partnership system which emphasizes on the mutual cooperation values. It is the cultural heritage value of rice farmers which is probably the process of acculturation between Javanese Hindustan-Buddhist cultures with Islamic cultural values. The mutual cooperation value takes role almost in all partnership forms in rice cultivation.

\subsection{The Meaning of Ta'awun}

The existence of PLS practice in rice cultivation also supports the spirit in mutual cooperation (ta' awun). The spirit of ta'awun is reflected in several managements of rice cultivation structures. The spirit of mutual help also becomes the good social capital for farmers. Several models of mutual cooperation, based on the practice in 
rice farmers, are as follows: (1) The meaning of ta'awun for landowner, (2) the meaning of ta'awun for the share croppers, (3) the meaning of ta'awun for the hodge, (4) the meaning of ta'awun for the person in charge of ngasak (look for the rice remain in the field) workers, (5) the meaning of ta'awun for the poor.

That kind of partnership conception, according to Engineer (2000), is relevant with the management principle of land farm cultivation applied by Prophet Mohammad SAW. Prophet Muhammad SAW applies the partnership system of profit and loss sharing in order to create social solidarity, the distribution mechanism of earnings, new job opportunity, and economic equality. The farm cultivation in form of musaqah, muzara'ah and mukhabarah as the execution of PLS partnership system applied by Prophet Muhammad has been made as a media to create brotherhood for mujahirin and anshar. Mujhirin is a group of people who migrate from Mecca to Medina. Brotherhood is made to maintain their relationship with anshar, the group of Muslim who are originally the native citizen of Medina. Professionally, Prophet Mohammad unites mujahirin who are mostly skilled in farm cultivation, and anshar who have farm fields in most.

1. Practice of Profit and Loss Sharing System (PLS).

\section{Conclusion}

a. Partnership as the Basis of PLS System

The development of rice cultivation technology and demographic growth cause the rice cultivation functioned as the source of staple food and as an occupation. The demographic development and demand of land ownership differentiate the rice cultivation into two: landowner and the sharecroppers. This thing demands management consequence of rice cultivation to do partnership.

b. Equity Capital

The high cost of capital financing of rice and the non-compatibility of financing facility with the finance management of rice cultivation encourage farmers to use equity capital of Profit and Loss Sharing (PLS) system as the major option in rice cultivation management. Thus, the financing models practiced by most rice farmers are based on equity financing.

c. PLS Model: One-Third Share and One-Half Share

The one-third share of PLS model is the partnership system which includes landowner and sharecroppers. The profit sharing composition uses the 2:1 formula which means that if three tons of rice achieved. The landowner receives 2 tons and the sharecropper gets 1 ton of rice.

Meanwhile, the one-half share of PLS model is a profit sharing system which is considered as the partnership of landowner and sharecropper with 1:1 formula. This explanation shows that the landowner and sharecropper share the profit and loss equally.

2. The Meanings of PLS for the Rice Farmers

a. The Meaning of Economic Equity

PLS will create an equity in economics because profit sharing is applied to maintain equality in a business. There is an equal relationship between the landowner and the sharecropper. This equity is reflected on the division of the proportional profit sharing system based on each contribution and role in rice cultivation.

b. The Meaning of Prosperity

In the PLS practice, not only the shareholder and stakeholder get the profit, but the surroundings also economically benefited from it. The profits are the existence of new business area, or business opportunities, such as muamalat transaction, the occurence of ijarah, mukhabarah, wadi'ah, rahn, bay' salam, bay' istishna', qardul hasan, and other thithes. PLS also affects the new business establishment such as culinary business, mushroom agribusiness, Saprodi kiosk, etc. Those new businesses establishment happen because of the needs occurred as affected by the existence of PLS based rice cultivation.

c. The Meaning of Partnership

PLS produces traditional value such as the spirit of partnership in economics. If any of the parties' members gets misfortune, the other citizens will help. In this common sense, the work done does not only need to be rewarded with money. In the practice of PLS, if they do not have money, the farmers can hire others whose job can be rewarded through doing the same thing if the associated farmers need someone to cultivate the farmland. There are many cooperation values in PLS which have worthy values for the landowner, sharecropper, majek workers, dereb workers and the hodges.

d. The Meaning of Ta'awun

The existence of PLS practice in rice cultivation can improve the spirit of cooperation (ta'awun) in the process of rice cultivation. The spirit of ta'awun is reflected on many rice cultivation management structures. The spirit of cooperation also becomes good social capital for the farmers' society.

\section{References}

[1] Antonio, M.S., 2001, Bank Syariah dari Teori ke Praktek, Gema Insani Press Tazkia Cendekia, Jakarta.

[2] Ashari dan Saptana, 2005, Prospek Pembiayaan Syariah untuk Sektor Pertanian, Forum Penelitian Agro Ekonomi, Vol. 23, N0. 2, Desember, h. 132-147. 
[3] Bank Indonesia,2006, Kamus Istilah Keuangan dan Perbankan Syariah, Direktorat Perbankan Syariah, Bank Indonesia.

[4] Bank Islam Malaysia Berhad, 1994, Islamic Banking Practice: From The Practitioner's Perspective, Kuala Lumpur Malaysia.

[5] Bashir, Abdel Hameed M, 2002, The Welfare Effects of Inflation and Financial Innovation in a Model of Economic Growth, An Islamic Perspective, Journal of Economic Studies, Vol. 29 No. 1, pp. 21-32.

[6] Chapra, M.Umar, 2000, Sistem Moneter Islam, Gema Insani Press, Jakarta.

[7] Choudhury, Masudul A, and Hussain, Md. Mostaque, 2005, A Paradigm of Islamic Money and Banking, International Journal of Social Economics, Vol. 32, No. 3, pp. 203-217.

[8] Engineer, Asghar Ali, 2000, Islamic State, Imam Mutaqin (penerjemah), Devolusi Negara Islam, Pustaka Pelajar.

[9] Giddens, Anthony, 1984, The Constitution of Society: Outline of the Theory of Structuration, Barkley, University of Calofornia Press.

[10] Haroen, Nasroen, 2000, Fiq Muamalah, Cet. 1, Gaya Media Pratama, Jakarta.

[11] Hasan, Zubair, 1985, Determination of Profit and Loss Sharing Ratios in Interest free Business Finance, Journal Research Islamic Economic, Vol. 3, No. 1, pp. 13-29.

[12] Hefner, Robert W, 2000, Amirudin dan Asyahbuddin (Penerjemah), Islam Pasar Keadilan, LKIS, Yogyakarta.

[13] Kuncoro, Haryo, 2002, Upah Sistem Bagi Hasil dan Penyerapan Tenaga Kerja, Jurnal Ekonomi Pembangunan, Vol. 7, No. 1, h. 45 56.

[14] Magnan, Michel, St-Onge, Sylvie and Cormier, Denis, 2005, The Adoption and Success of Profit-Sharing Plans in Strategic Business Units: Opportunism or Contingency?, International Journal of Productivity and Performance Management, Vol. 54, No. $5 / 6$, pp. 335-369

[15] Mubyarto,2003, Demokrasi Ekonomi dan Demokrasi Industrial, www.ekonomirakyat.org.

[16] Muhammad, 2005, Penyesuaian Masalah Agensi (Agency Problem) dalam Kontrak Pembiayaan Mudharabah, www.goole.com.

[17] Mustopo, Moehamad Habib, 2001, Kebudayaan Islam di Jawa Timur: Kajian Beberapa Unsur Budaya Masa Peralihan, Penerbit Jendela, Yogyakarta.

[18] Nienhaus, Volker, 1403/1983, Profitability of Islamic PLS Banks Competing with Interest Banks: Problems and Prospects, Journal Research Islamic Economic, Vol.1, No. 1, pp. 31-39.

[19] Perwataatmadja, Karnaen, 1996, Membumikan Ekonomi Islam di Indonesia, Usaha Kami, Jakarta.

[20] Qardhawi, Yusuf, 2002, Fatawa Mu'ashirah, Samson Rahman, dkk. (penerjemah), Fatwa-fatwa Kontemporer 3, Pustaka AlKautsar, Jakarta.

[21] Rosly, Saiful Azhar, 2005, Critical Issues on Islamic Bangking and Financial Markets, Dinamas Publishing, Kuala Lumpur Malaysia.

[22] Sajogyo, 2002, Pertanian dan Kemiskinan, Jurnal Ekonomi Rakyat, Th.1, No. 1, www.ekonomirakyat.org.

[23] Tetanel, Yauri. 2008, Globalisasi dan Nasib Pertanian Indonesia, Seminar Nasional Kedaulatan Pangan Fateta UGM, 23 Agustus 2008.

[24] Yasin, Muhammad, 2008, Kebijakan “Kredit Panen” Sebagai Instrumen Guna Mengangkat Petani Padi Dari Kemiskinan, Jurnal Ichsan Gorontalo, Vol. 3, No. 1, Februari. 